ORNL/TM-2017/241

\title{
Comparison of Microclimate Simulated weather data to ASHRAE Clear Sky Model and Measured Data
}

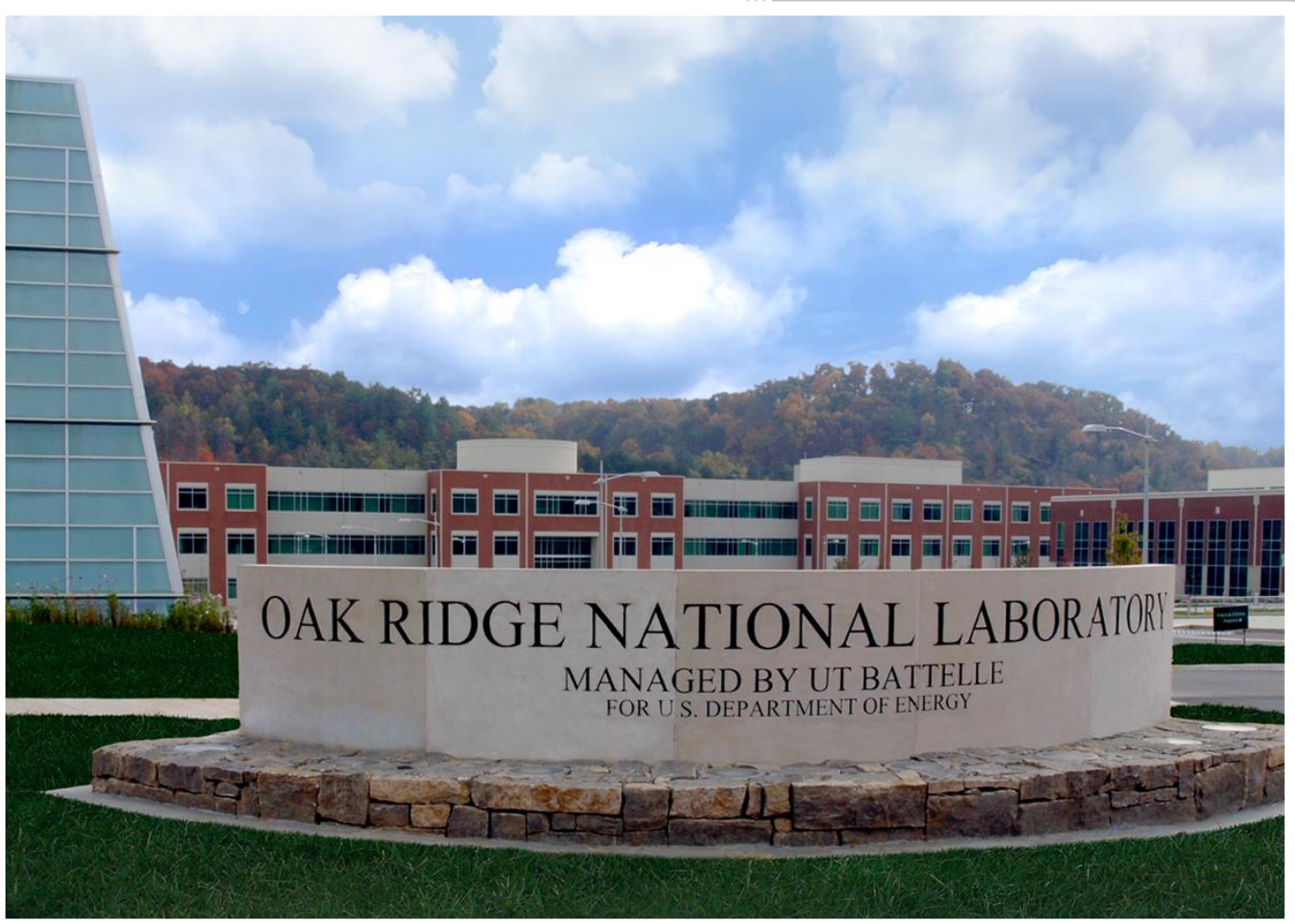

\section{Approved for public release.} Distribution is unlimited.
Mahabir S. Bhandari, Ph.D. Som S. Shrestha, Ph.D. Joshua R. New, Ph.D. Melissa R. Allen, Ph.D.

July 19, 2017 


\section{DOCUMENT AVAILABILITY}

Reports produced after January 1, 1996, are generally available free via US Department of Energy (DOE) SciTech Connect.

Website http://www.osti.gov/scitech/

Reports produced before January 1, 1996, may be purchased by members of the public from the following source:

National Technical Information Service

5285 Port Royal Road

Springfield, VA 22161

Telephone 703-605-6000 (1-800-553-6847)

TDD 703-487-4639

Fax 703-605-6900

E-mail info@ntis.gov

Website http://www.ntis.gov/help/ordermethods.aspx

Reports are available to DOE employees, DOE contractors, Energy Technology Data Exchange representatives, and International Nuclear Information System representatives from the following source:

Office of Scientific and Technical Information

PO Box 62

Oak Ridge, TN 37831

Telephone 865-576-8401

Fax 865-576-5728

E-mail reports@osti.gov

Website http://www.osti.gov/contact.html

This report was prepared as an account of work sponsored by an agency of the United States Government. Neither the United States Government nor any agency thereof, nor any of their employees, makes any warranty, express or implied, or assumes any legal liability or responsibility for the accuracy, completeness, or usefulness of any information, apparatus, product, or process disclosed, or represents that its use would not infringe privately owned rights. Reference herein to any specific commercial product, process, or service by trade name, trademark, manufacturer, or otherwise, does not necessarily constitute or imply its endorsement, recommendation, or favoring by the United States Government or any agency thereof. The views and opinions of authors expressed herein do not necessarily state or reflect those of the United States Government or any agency thereof. 
Energy and Transportation Sciences Division

\title{
COMPARISON OF MICROCLIMATE SIMULATED WEATHER DATA TO ASHRAE CLEAR SKY MODEL AND MEASURED DATA
}

\author{
Mahabir S. Bhandari \\ Som S. Shrestha \\ Joshua R. New \\ Melissa R. Allen
}

Date Published: July 19, 2017

\author{
Prepared by \\ OAK RIDGE NATIONAL LABORATORY \\ Oak Ridge, Tennessee 37831-6283 \\ managed by \\ UT-BATTELLE, LLC \\ for the \\ US DEPARTMENT OF ENERGY \\ under contract DE-AC05-00OR22725
}





\section{CONTENTS}

LIST OF FIGURES
LIST OF TABLES
ACRONYMS
ABSTRACT
1.
INTRODUCTION





\section{LIST OF FIGURES}

Figure

Figure 1. ASHRAE Clear Sky Model's predicted maximum direct normal irradiance for ORNL for a day from each season assuming a clear sky.

Figure 2. Weather station on the roof of ORNL's two-story Flexible Research Platform (FRP2) captures all weather data needed to accurately model whole-building energy consumption.

Figure 3. Comparison between ACSM predicted and ENVI-met calculated direct normal irradiance for June 21, 2013 at the ORNL campus shows physically-unrealistic radiation levels and temporal shift.

Figure 4. Comparison among ACSM predicted, measured, and ENVI- met calculated direct normal irradiance for Dec 21, 2013 at the ORNL campus shows little correlation between the simulated and actual solar irradiance.

Figure 5: Comparisons between WRF calculated (purple) and measured data (blue) for January 2015 at Oak Ridge, TN show the degree of agreement for Temperature, Relative

Humidity, Barometric Pressure, Wind Speed, and Wind Direction. 16

Figure 6. Rose diagram of wind speed and direction of measured (left) and WRF-simulated (right) allow qualitative comparison of differences. WRF-simulated wind speed tends to be 2$3 \mathrm{x}$ stronger, has no calm events, and blows more omni-directionally

Figure 7. Box-and-whisker plots of hourly dry bulb, relative humidity, wind speed, direct normal irradiance (DNI), and diffuse horizontal irradiance (DHI) for each month shows the statistical differences between measured and simulated weather variables. Lines show the maximum and minimum value, where vertical bars meet is the average monthly data value, bars show the $25-50^{\text {th }}$ percentile and $50-75^{\text {th }}$ percentile of hourly data for that month. Charts for DNI, and DHI show data for daylight hours only.

Figure 8: Frequency distribution of values within specific weather variables.......................................... 19

Figure 9: Frequency distribution of values within specific weather variables....................................... 20

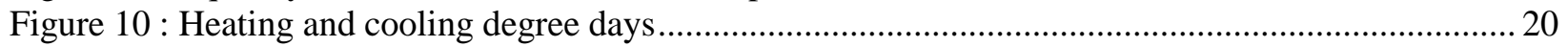

Figure 11: EnergyPlus model of buildings: (a) Building 1, (b) Building 2 and (c) Building 3 ................ 21

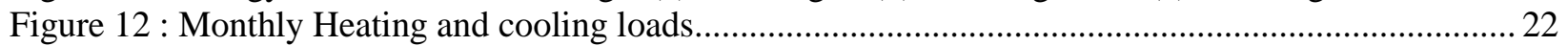

Figure 13 : Annual energy consumption using measured weather data as well where individual parameters from Set 1 are used to replace the measured weather data for variables including: dry bulb temperature (DB), relative humidity (RH), direct normal irradiance (DNI), diffuse horizontal irradiance (DHI)and wind speed (WS). 



\section{LIST OF TABLES}

\section{Table}

Page

Table 1. The hardware and sensors used in this study to measure individual weather parameters that are most important for accurate whole-building energy simulation..................................... 14

Table 2. WRF's nested grid sizes used for modeling microclimate of ORNL. Each of these domains used "Single Moment 3-class" Microphysics, "New Goddard" Radiation, "Xu-Randall" Cloud Fraction, "Morin-Obukhov" Surface Physics, "Noah" Land, and "BouLac" Planetary Boundary Layer whereas Cumulus and Urban Parameters varied...

Table 3. Statistical summary of measured and WRF (Set1) $270 \mathrm{~m}$ hourly weather data for major weather variables during 2015. This data could be used to prioritize or correct bias between measured and simulated data.

Table 4. Variation in annual energy consumption with respect to weather data 



\section{ACRONYMS}

$\begin{array}{ll}\text { ACSM } & \text { ASHRAE Clear Sky Model } \\ \text { BESTEST } & \text { Building Energy Simulation Test } \\ \text { BTRIC } & \text { Building Technologies Research and Integration Center } \\ \text { CESM } & \text { Community Earth System Model } \\ \text { CSV } & \text { Comma-Separated Values } \\ \text { DB } & \text { Dry Bulb temperature } \\ \text { DOE } & \text { Department of Energy } \\ \text { DHI } & \text { Diffuse Horizontal Irradiance } \\ \text { DNI } & \text { Direct Normal Irradiance } \\ \text { FRP } & \text { Flexible Research Platform } \\ \text { HERS } & \text { Home Energy Rating System } \\ \text { HVAC } & \text { Heating, Ventilation and Air Conditioning } \\ \text { LiDAR } & \text { Light Detection and Ranging } \\ \text { NCAR } & \text { National Center for Atmospheric Research } \\ \text { ORNL } & \text { Oak Ridge National Laboratory } \\ \text { PGI } & \text { Portland Group } \\ \text { RH } & \text { Relative Humidity } \\ \text { TMY } & \text { Typical Meteorological Year } \\ \text { Urban-MET } & \text { Urban Microclimate and Energy Tool } \\ \text { WRF } & \text { Weather Research Forecast } \\ \text { WS } & \text { Wind Speed }\end{array}$





\begin{abstract}
In anticipation of emerging global urbanization and its impact on microclimate, a need exists to better understand and quantify microclimate effects on building energy use. Satisfaction of this need will require coordinated research of microclimate impacts on and from "human systems." The Urban Microclimate and Energy Tool (Urban-MET) project seeks to address this need by quantifying and analyzing the relationships among climatic conditions, urban morphology, land cover, and energy use; and using these relationships to inform energy-efficient urban development and planning. Initial research will focus on analysis of measured and modeled energy efficiency of various building types in selected urban areas and temporal variations in energy use for different urban morphologies under different microclimatic conditions. In this report, we analyze the differences between microclimate weather data sets for the Oak Ridge National Laboratory campus produced by ENVI-met and Weather Research Forecast (WRF) models, the ASHRAE clear sky which defines the maximum amounts of solar radiation that can be expected, and measured data from a weather station on campus. Errors with climate variables and their impact on building energy consumption will be shown for the microclimate simulations to help prioritize future improvement for use in microclimate simulation impacts to energy use of buildings.
\end{abstract}

\title{
1. INTRODUCTION
}

\subsection{SIGNIFICANCE}

Comprising only $4.4 \%$ of the world's population, the United States consumes $19 \%$ of the world's primary energy production. Buildings account for the largest fraction of energy consumption at $41 \%$ of primary energy used in 2010. This energy consumption amounts to $40 \%$ of total U.S. $\mathrm{CO}_{2}$ emissions, contributing significantly to global warming and to regional climate change [1]. Climate change impacts, urban and population growth, and concomitant increases in energy demands (particularly for developing economies) have the potential to alter regional energy consumption patterns as more humans respond to new climate conditions. This new consumption currently results in additional greenhouse gas emissions that accelerate ecological change [2].

Climate conditions are primary drivers of heating and cooling demand for buildings. Specifically, urban microclimate - determined by local meteorology, solar irradiance and reflection, air temperature, humidity, wind velocity, and ground temperature - can affect building energy demand. Buildings within an urban setting must generally respond to higher ambient temperatures due to radiative heat exchange between neighboring buildings, convective heat transfer due to wind patterns within a group of buildings, thermal mass of city infrastructure, and Urban Heat Island effects [3]. These thermodynamic properties for urban settings typically help offset heating demand during colder months but may lead to higher cooling demand in the summer [4].

Other recent studies [5][6][7] have examined impacts of climate change on energy consumption. These studies used building energy models to develop hypothetical communities of statistically representative building typologies and to generate hourly building energy demand for these communities; but there is limited evaluation of microclimate effects regarding building proximity, height, and 3D configuration of cities (morphology). Progress in this area has been limited by the lack of available climate data at resolutions needed, lack of a methodology for quantifying the amount of solar insolation (considering latitude and season) on individual building rooftops, and by lack of access to 3D datasets of urban land surface at urban scales. With recent acquisition of satellite, Light Detection and Ranging (LiDAR), and other data 
sources, ORNL can now generate 3D building morphology for any geographic region, where the information is available. ORNL-developed deep learning on multispectral images can now reliably infer building roof radiation, thermal conductivity, heat capacity and emissivity of buildings, as well as neighboring land cover [8]. In addition, ORNL is working toward increasing the resolution of WRF from $1 \mathrm{~km}$ grid cells to 10 - meter grid cells using embedded large eddy simulations (LES). We have succeeded at simulating 90m resolution results using $10 \mathrm{~m}$ urban topography input. These highly-resolved building and climate interfaces allow analysis of existing urban-scale impact of the built environment by understanding buildingspecific microclimate impact of weather around the building.

\subsection{MICROCLIMATE SIMULATION}

There is a growing need to model the urban microclimate using newly-available high-resolution inputs derived from recent advances in data resolution and computationally-derived products. The Urban-MET project aims to address two climatically distinct cities, Oak Ridge, Tennessee and Chicago, Illinois by creating climate model output at 0.125-degree latitude and longitude resolution. For this, the team used the North American Regional Reanalysis 2015 data as initial and boundary conditions for both the ENVImet and the Weather Research and Forecasting (WRF) models along with building-level thermal properties, radiative and morphological properties obtained from various LiDAR and multispectral imagery to develop $10 \mathrm{~m}$ resolution building topography readable by the models.

ENVI-met (http://www.envi-met.com/documents/onlinehelpv3/helpindex.htm), based on computational fluid dynamics and thermodynamics, is capable of simulating airflow around and between buildings, exchange processes of heat and water vapor at urban surfaces, turbulence, exchanges of energy and mass between vegetation and its surroundings, particle dispersion, and simple chemical reactions, all at a spatial resolution of $0.5-5 \mathrm{~m}$ and temporal resolution of $1-10 \mathrm{~s}$. LiDAR data is used to generate 3D building configurations for the model simulation, and multispectral imagery is used to infer the initial and boundary conditions of building roof radiation [8], thermal conductivity, heat capacity and emissivity, as well as neighboring land cover (e.g., vegetation and bare ground). These are produced by taking into account differences in sun angle (due to differences in location latitude), changes in sun intensity (due to seasonality), and provide a mechanism for adjustment of solar access due to "neighboring effects" of nearby buildings and vegetation.

WRF (http://www.wrf-model.org/index.php) is a mesoscale numerical weather prediction system designed for both atmospheric research and operational forecasting needs and is updated by the weather forecasting community as advances in physics, calculation, and data assimilation procedures are contributed and vetted. It features two dynamical cores: a data assimilation system, and a software architecture facilitating parallel computation with system extensibility. The model typically serves a wide range of meteorological applications across scales from tens to thousands of kilometers.

\section{DATA SOURCES}

\subsection{ASHRAE CLEAR SKY MODEL}

Several solar models exist with varying complexity to calculate solar radiation during clear sky conditions. Among the available models, ASHRAE Clear Sky Model [10] is the commonly used method to estimate solar heat load for building designs. This is the default model used in EnergyPlus, the 
Department of Energy's (DOE) flagship whole-building simulation tool [11], to estimate clear-day solar radiation for any day/month of the year. The ASHRAE Clear Sky Model (ACSM) was initially developed for the U.S. or similarly temperate climates in the northern hemisphere. EnergyPlus calculations extend the clear sky application to both northern and southern hemispheres. ACSM calculates direct normal and diffuse horizontal irradiances as a function of extraterrestrial normal irradiance, beam pseudo optical depth, relative air mass, and beam air mass exponent. Further ACSM details are disclosed in Chapter 12 of the ASHRAE Handbook of Fundamentals (2013). As shown in Figure 1, ACSM identifies the predicted direct normal irradiance, on a day from each of the seasons, which should be expected during a clear sky (and with flat horizons) at the ORNL campus.

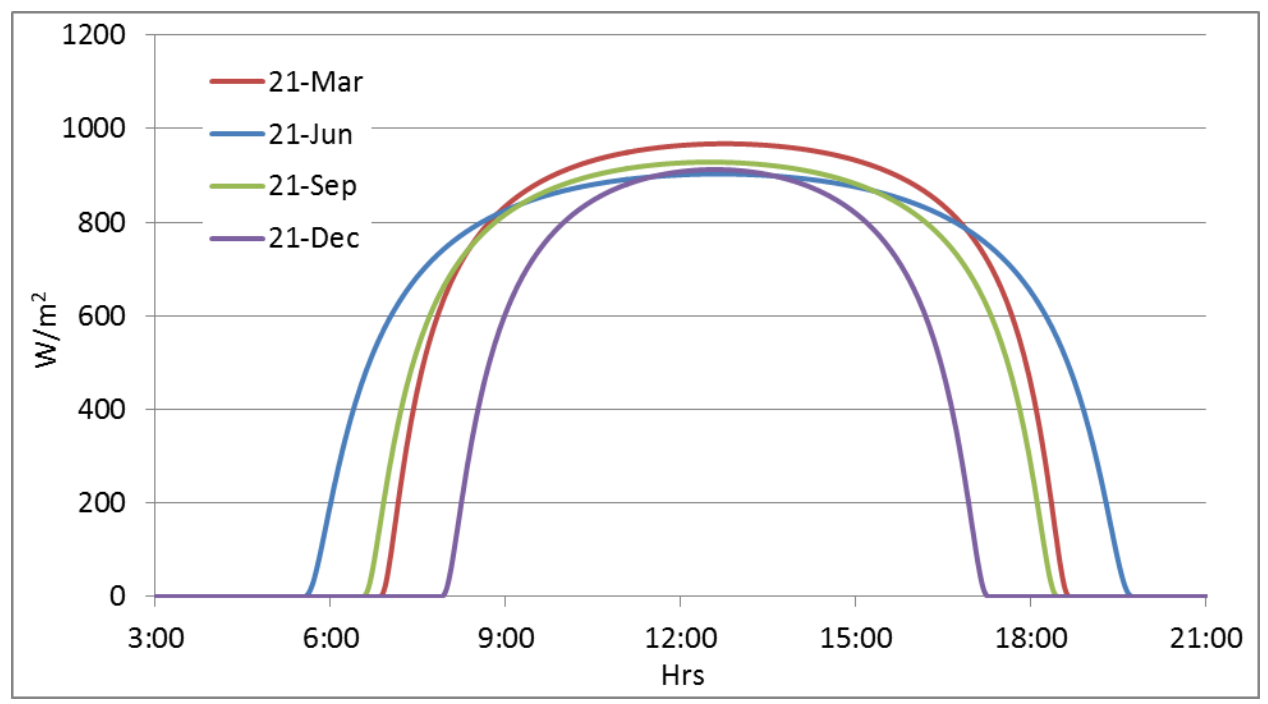

Figure 1. ASHRAE Clear Sky Model's predicted maximum direct normal irradiance for ORNL for a day from each season assuming a clear sky.

\subsection{WEATHER STATION}

A dedicated weather station, as shown in Figure 2, is installed on the roof of ORNL's two-story Flexible Research Platform (FRP) building [12]. All weather parameters necessary for building energy modeling are being measured at 30-second intervals and aggregated to produce 15-minute and hourly interval data typical for annual building energy simulations. The annual hourly measured data are formatted in Typical Meteorological Year (TMY) format to allow simulations of ORNL buildings using EnergyPlus. The measured data will also be used as a benchmark to empirically validate accuracy of microclimate simulations.
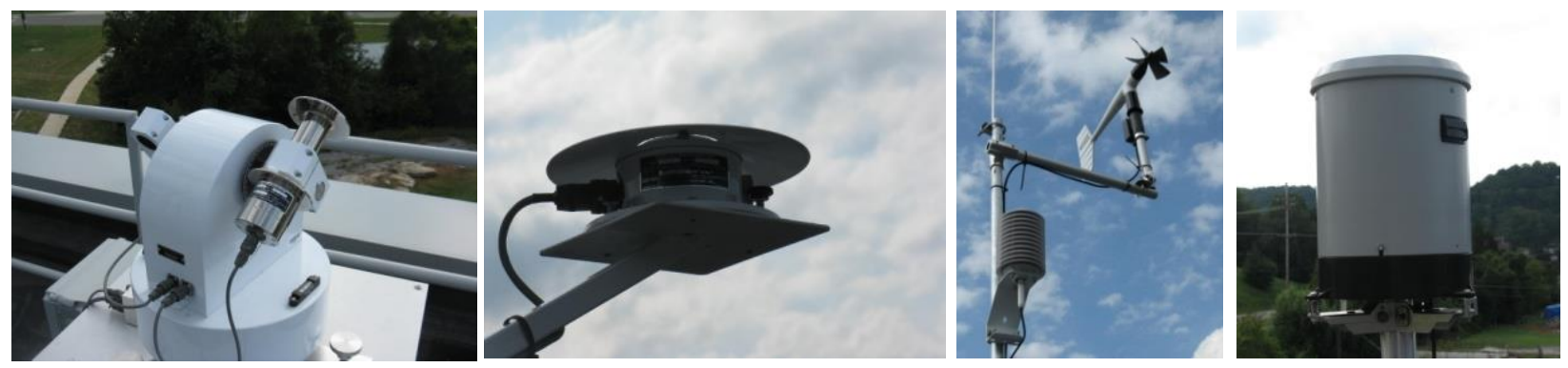

Figure 2. Weather station on the roof of ORNL's two-story Flexible Research Platform (FRP2) captures all weather data needed to accurately model whole-building energy consumption. 
Table 1. The hardware and sensors used in this study to measure individual weather parameters that are most important for accurate whole-building energy simulation.

\begin{tabular}{|l|c|c|}
\hline \multicolumn{1}{|c|}{ Parameters } & Company & Model number \\
\hline Temperature & Campbell Scientific & CS215 \\
\hline Relative humidity & Campbell Scientific & CS215 \\
\hline Wind speed/direction & Gill & WindSonic \\
\hline Rainfall & Texas Electronics & TE525WS \\
\hline Global Horizontal irradiance & Eppley & SPP \\
\hline Direct beam irradiance & Eppley & NIP \\
\hline IR radiation from sky & Eppley & PIR \\
\hline Atmospheric pressure & Vaisala & CS106 \\
\hline
\end{tabular}

\subsection{MICROCLIMATE SIMULATION}

The urban microclimate was modeled using WRF Version 3.7.1, compiled with the Portland Group (PGI) compiler in order to allow parallel execution on ORNL's Titan supercomputer ( $3^{\text {rd }}$-fastest high performance computing system in the world as of the time of this report). Ultimately, six nested domains will be run for each of the ORNL campus and the Chicago Loop. To begin, however, three nested domains were run for the ORNL campus and two nested domains were run for the Chicago Loop area. Horizontal resolution for each of the domains are 6,750 meters, 1,350 meters, and 270 meters respectively with 41 vertical levels and a model top of $100 \mathrm{hPa}$ as defined by the NARR dataset used as initial and boundary conditions. The time step used for the outermost $(6,750 \mathrm{~m})$ domain was 10 seconds. The time step for each nested grid was in the same ratio to the outer domain as was its spatial dimension. Grid sizes and details of the nested domain physics packages used in this study are summarized in Table 2. Physics packages for WRF were chosen based on optimum packages for urban scenarios and on radiation profiles. Post processing of WRF data was performed using the National Center for Atmospheric Research (NCAR) Command Language for output into Comma-Separated Values (*.csv) files that were subsequently translated to EnergyPlus Weather Files (*.epw)[14]. This building-specific weather file is the only microclimate/building energy coupling mechanism utilized in this study.

Table 2. WRF's nested grid sizes used for modeling microclimate of ORNL. Each of these domains used "Single Moment 3 class" Microphysics, "New Goddard" Radiation, "Xu-Randall" Cloud Fraction, "Morin-Obukhov" Surface Physics, "Noah" Land, and "BouLac" Planetary Boundary Layer whereas Cumulus and Urban Parameters varied.

\begin{tabular}{|l|l|l|l|l|l|l|}
\hline \multicolumn{1}{|c|}{ Location } & \multicolumn{1}{c|}{ D01 } & \multicolumn{1}{c|}{ D02 } & \multicolumn{1}{c|}{ D03 } & \multicolumn{1}{c|}{ D04 } & \multicolumn{1}{c|}{ D05 } & \multicolumn{1}{c|}{ D06 } \\
\hline Oak Ridge & $100 \times 100$ & $85 \times 95$ & $80 \times 90$ & $96 \times 90$ & $96 \times 108$ & $144 \times 176$ \\
\hline Chicago & $100 \times 100$ & $85 \times 95$ & $95 \times 105$ & $96 \times 90$ & $96 \times 108$ & $123 \times 216$ \\
\hline & & & & & & \\
\hline Cumulus & Kain-Fritsch & Kain-Fritsch & $\begin{array}{l}\text { Betts-Miller- } \\
\text { Janjic }\end{array}$ & $\begin{array}{l}\text { Betts-Miller- } \\
\text { Janjic }\end{array}$ & $\begin{array}{l}\text { Betts-Miller- } \\
\text { Janjic }\end{array}$ & $\begin{array}{l}\text { Betts-Miller- } \\
\text { Janjic }\end{array}$ \\
\hline Urban Params & $\begin{array}{l}\text { Urban } \\
\text { Canopy }\end{array}$ & $\begin{array}{l}\text { Urban } \\
\text { Canopy }\end{array}$ & ORNL New & ORNL New & ORNL New & ORNL New \\
\hline
\end{tabular}




\section{RESULTS}

\subsection{ENVI-MET VS. CLEAR SKY AND WEATHER DATA}

ENVI-met data for June 21 and Dec 21, 2013 were plotted against the ASHRAE clear sky model. ENVImet showed direct normal irradiance higher than ACSM predicted values for June 21 and is also timeshifted, as shown in Figure 3. Local weather station data shows that Dec 21was a cloudy day, but ENVImet data shows, in Figure 4, this day to be a nearly clear day. There is generally minimal correlation between measured and ENVI-met calculated solar radiation and therefore, the ENVI-MET data would not be used for further analysis.

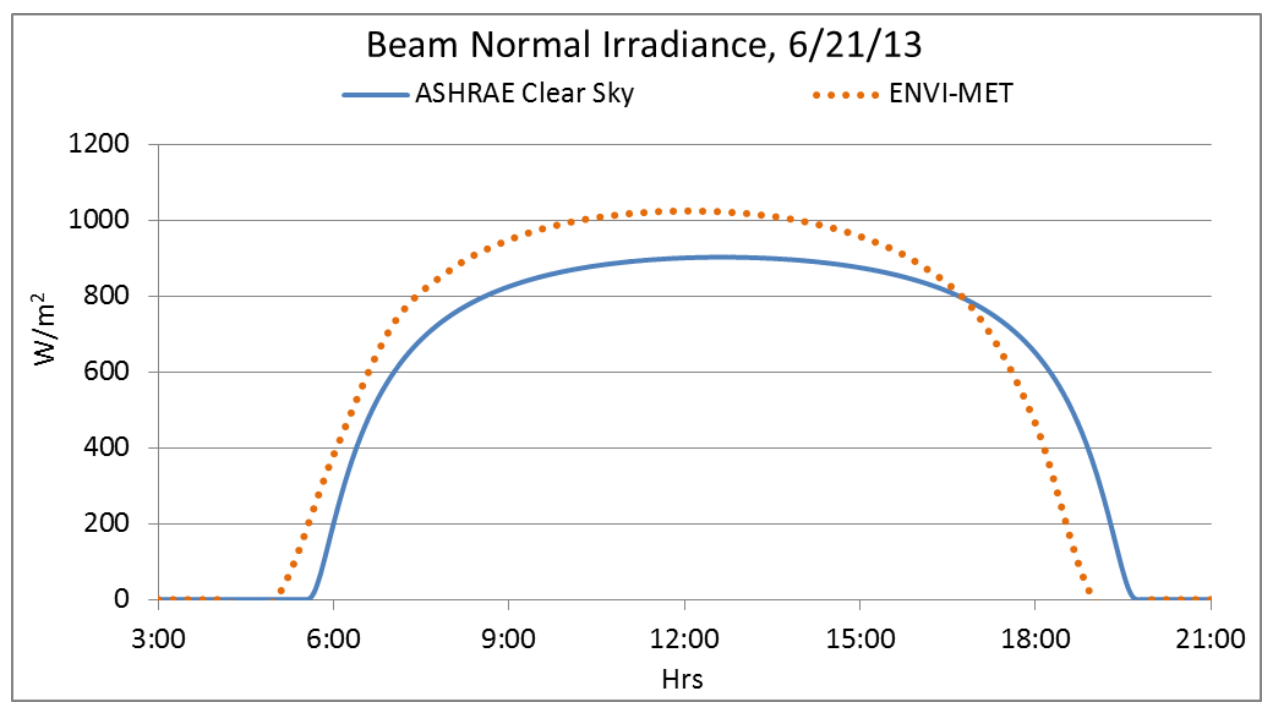

Figure 3. Comparison between ACSM predicted and ENVI-met calculated direct normal irradiance for June 21, 2013 at the ORNL campus shows physically-unrealistic radiation levels and temporal shift.

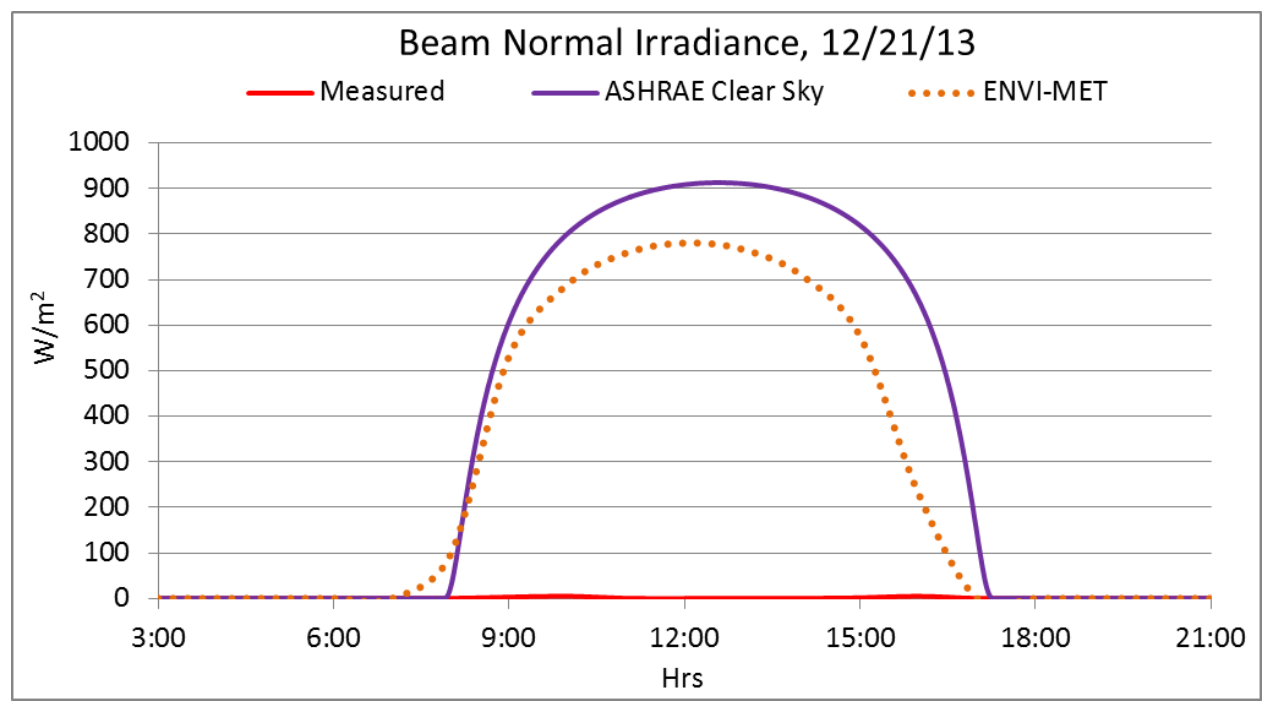

Figure 4. Comparison among ACSM predicted, measured, and ENVI- met calculated direct normal irradiance for Dec 21, 2013 at the ORNL campus shows little correlation between the simulated and actual solar irradiance. 


\subsection{WRF VS. MEASURED WEATHER DATA PRELIMINARY ANALYSIS}

After finding several short-comings with ENVI-met generated data, the Weather Research Forecast (WRF) model was selected for further simulations. Data was further refined for the ORNL Campus and included additional weather variables such as temperature, humidity, pressure, window speed and wind direction.

\subsubsection{SHORT TERM COMPARISON OF MEASURED AND MODELED DATA}

Hourly data for January 2015 at 90 meter spatial resolution (domain 4) from the WRF model at three locations corresponding to ORNL campus meteorological towers (referred to as Tow A, Tow B and Tow D) were compared to measured data for dry bulb temperature, Relative Humidity (RH), pressure, wind speed and wind directions as shown in Figure 5.

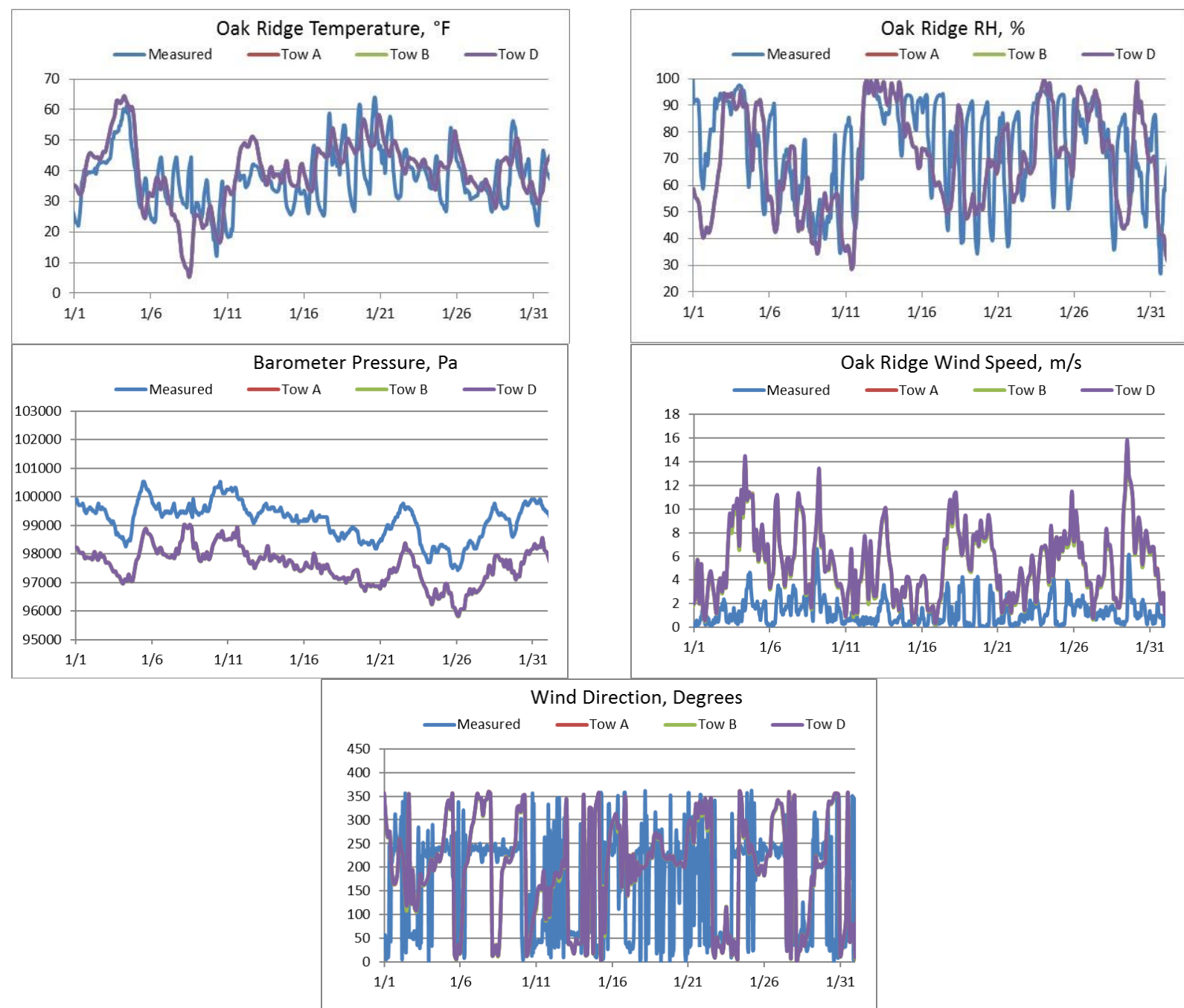

Figure 5: Comparisons between WRF calculated (purple) and measured data (blue) for January 2015 at Oak Ridge, TN show the degree of agreement for Temperature, Relative Humidity, Barometric Pressure, Wind Speed, and Wind Direction.

Major weather variables required for whole building energy modeling are compared statistically to allow detailed characterization of each meteorological variable that facilitates prioritization for improvements in future work or simpler bias-correction methods. 
Table 3. Statistical summary of measured and WRF (Set1) 270m hourly weather data for major weather variables during 2015. This data could be used to prioritize or correct bias between measured and simulated data.

\begin{tabular}{|c|c|c|c|c|c|c|c|}
\hline Variable & Statistic & Meas & Set 1 & Variable & Statistic & Meas & Set 1 \\
\hline \multirow[t]{13}{*}{ Dry Bulb } & Mean & 15.25 & 15.50 & \multirow{13}{*}{\begin{tabular}{|l} 
Direct \\
Normal \\
Irradiance \\
$(\mathrm{W} / \mathbf{m} 2)$
\end{tabular}} & \begin{tabular}{|l|} 
Mean \\
\end{tabular} & \begin{tabular}{|l|}
146.02 \\
\end{tabular} & $\begin{array}{r}2.45 \\
\end{array}$ \\
\hline & Median & 16.84 & 17.50 & & Median & 0.32 & 3.57 \\
\hline & Deviation & 9.51 & 8.44 & & Deviation & 266.70 & 430.80 \\
\hline & $\mathrm{MBE}$ & & -0.25 & & MBE & & 143.57 \\
\hline & MAPE & & 0.38 & & MAPE & & 1648.54 \\
\hline & RMSE & & 4.34 & & RMSE & & 461.37 \\
\hline & CV-RMSE & & 0.28 & & CV-RMSE & & 3.16 \\
\hline & $\mathrm{r} 2$ & & 0.79 & & $\mathrm{r} 2$ & & 0.08 \\
\hline & Kurtosis & -0.40 & 0.04 & & Kurtosis & 1.30 & -1.02 \\
\hline & Skewness & -0.49 & -0.77 & & Skewness & 1.66 & -0.01 \\
\hline & Minimum & -16.88 & -14.40 & & Minimum & -0.12 & -811.08 \\
\hline & Maximum & 33.89 & 32.50 & & Maximum & 988.00 & 811.08 \\
\hline & Conf $(95 \%)$ & 0.20 & 0.18 & & Conf $(95 \%)$ & 5.58 & 9.02 \\
\hline \multirow[t]{13}{*}{ Dew Point } & Mean & 3.69 & 9.27 & \multirow{13}{*}{\begin{tabular}{|l|} 
Diffuse \\
Irradiance \\
$(\mathrm{W} / \mathrm{m} 2)$
\end{tabular}} & Mean & 80.16 & 23.16 \\
\hline & Median & 13.26 & 12.50 & & Median & 6.54 & 0.04 \\
\hline & \begin{tabular}{|l|} 
Deviation \\
\end{tabular} & 25.22 & 10.21 & & \begin{tabular}{|l|} 
Deviation \\
\end{tabular} & 129.34 & 34.94 \\
\hline & $\mathrm{MBE}$ & & -5.59 & & $\mathrm{MBE}$ & & 57.00 \\
\hline & MAPE & & 0.33 & & MAPE & & 94.36 \\
\hline & RMSE & & 19.95 & & RMSE & & 143.41 \\
\hline & CV-RMSE & & 5.41 & & CV-RMSE & & 1.79 \\
\hline & $\mathrm{r} 2$ & & 0.53 & & r2 & & 0.00 \\
\hline & Kurtosis & 3.21 & -0.07 & & Kurtosis & 8.69 & 1.44 \\
\hline & Skewness & -2.09 & -0.87 & & Skewness & 2.51 & 1.54 \\
\hline & Minimum & -79.99 & -25.20 & & Minimum & 0.00 & 0.00 \\
\hline & Maximum & 25.19 & 23.80 & & Maximum & $1,001.00$ & 150.58 \\
\hline & Conf $(95 \%)$ & 0.53 & 0.21 & & Conf $(95 \%)$ & 2.71 & 0.73 \\
\hline \multirow[t]{13}{*}{ RH } & Mean & 76.06 & 68.88 & \multirow{13}{*}{$\begin{array}{l}\text { Wind } \\
\text { Speed } \\
(\mathrm{m} / \mathrm{s})\end{array}$} & Mean & 1.09 & 3.24 \\
\hline & Median & 81.80 & 71.10 & & Median & 0.76 & 2.78 \\
\hline & Deviation & 20.20 & 18.33 & & \begin{tabular}{|l|} 
Deviation \\
\end{tabular} & 0.99 & 2.13 \\
\hline & MBE & & 7.18 & & \begin{tabular}{|l|}
$\mathrm{MBE}$ \\
\end{tabular} & & -2.15 \\
\hline & MAPE & & 0.25 & & MAPE & & 13.00 \\
\hline & RMSE & & 21.50 & & RMSE & & 3.07 \\
\hline & CV-RMSE & & 0.28 & & CV-RMSE & & 2.82 \\
\hline & $\mathrm{r} 2$ & & 0.20 & & $\mathrm{r} 2$ & & 0.03 \\
\hline & Kurtosis & -0.45 & -0.78 & & Kurtosis & 1.95 & 1.53 \\
\hline & Skewness & -0.75 & -0.37 & & Skewness & 1.39 & 1.21 \\
\hline & Minimum & 9.95 & 19.80 & & Minimum & 0.00 & 0.00 \\
\hline & Maximum & 100.00 & 107.80 & & Maximum & 6.64 & 13.76 \\
\hline & Conf $(95 \%)$ & 0.42 & 0.38 & & Conf $(95 \%)$ & 0.02 & 0.04 \\
\hline \multirow{13}{*}{\begin{tabular}{|l} 
Wind \\
Direction \\
(degrees)
\end{tabular}} & Mean & 134.93 & 175.78 & & & & \\
\hline & Median & 78.00 & 195.96 & & & & \\
\hline & \begin{tabular}{|l|} 
Deviation \\
\end{tabular} & 105.68 & 106.50 & & & & \\
\hline & $\mathrm{MBE}$ & & -40.85 & & & & \\
\hline & MAPE & & 3.05 & & & & \\
\hline & \begin{tabular}{|l|} 
RMSE \\
\end{tabular} & & 140.24 & & & & \\
\hline & CV-RMSE & & 1.04 & & & & \\
\hline & $\mathrm{r} 2$ & & 0.04 & & & & \\
\hline & Kurtosis & -1.40 & -1.34 & & & & \\
\hline & Skewness & 0.36 & -0.04 & & & & \\
\hline & Minimum & 0.00 & 0.03 & & & & \\
\hline & Maximum & 360.00 & 359.99 & & & & \\
\hline & Conf $(95 \%)$ & 2.21 & 2.23 & & & & \\
\hline
\end{tabular}


Table 3 shows WRF simulated data matches well with dry bulb temperature, which is one of the most important variables for energy consumption of buildings. However, there is still a significant mismatch between other variables. Wind speed and direction are displayed in a rose diagram as shown in Figure 6. The whisker plot comparison data for temperature, humidity, direct normal and diffuse horizontal are shown in Figure 7.
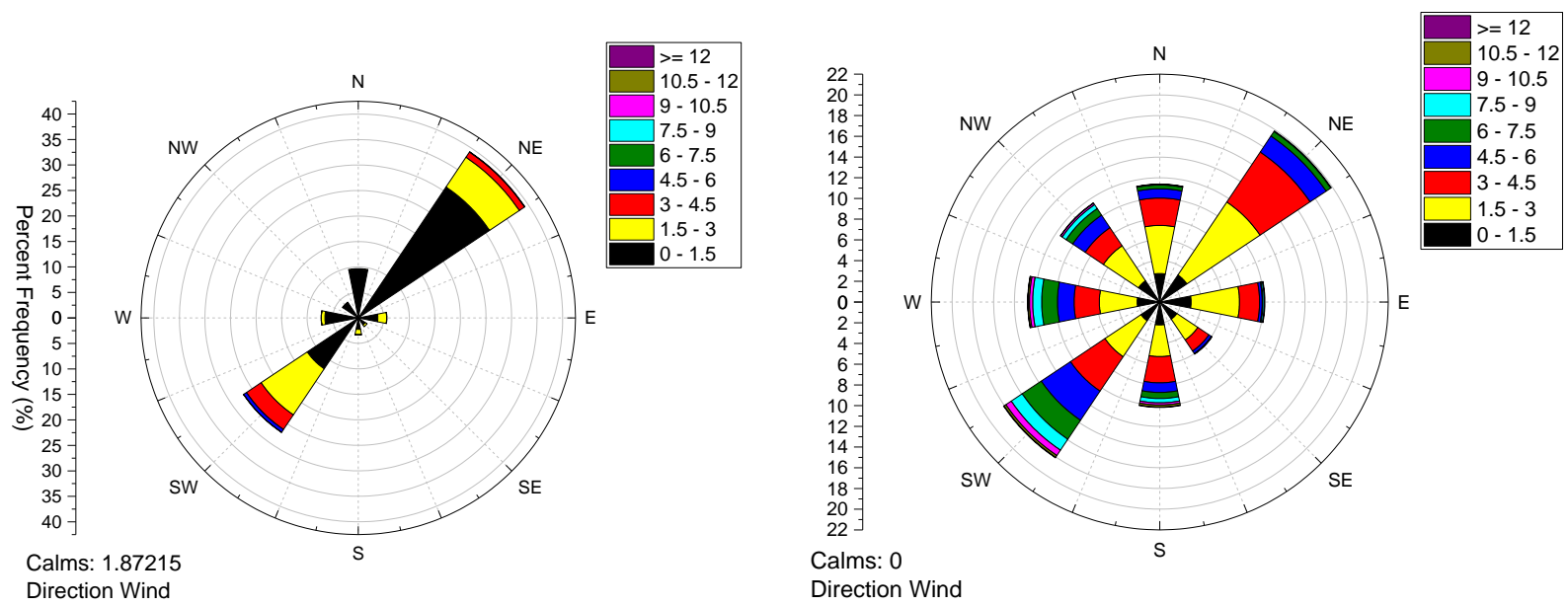

Figure 6. Rose diagram of wind speed and direction of measured (left) and WRF-simulated (right) allow qualitative comparison of differences. WRF-simulated wind speed tends to be 2-3x stronger, has no calm events, and blows more omni-directionally.
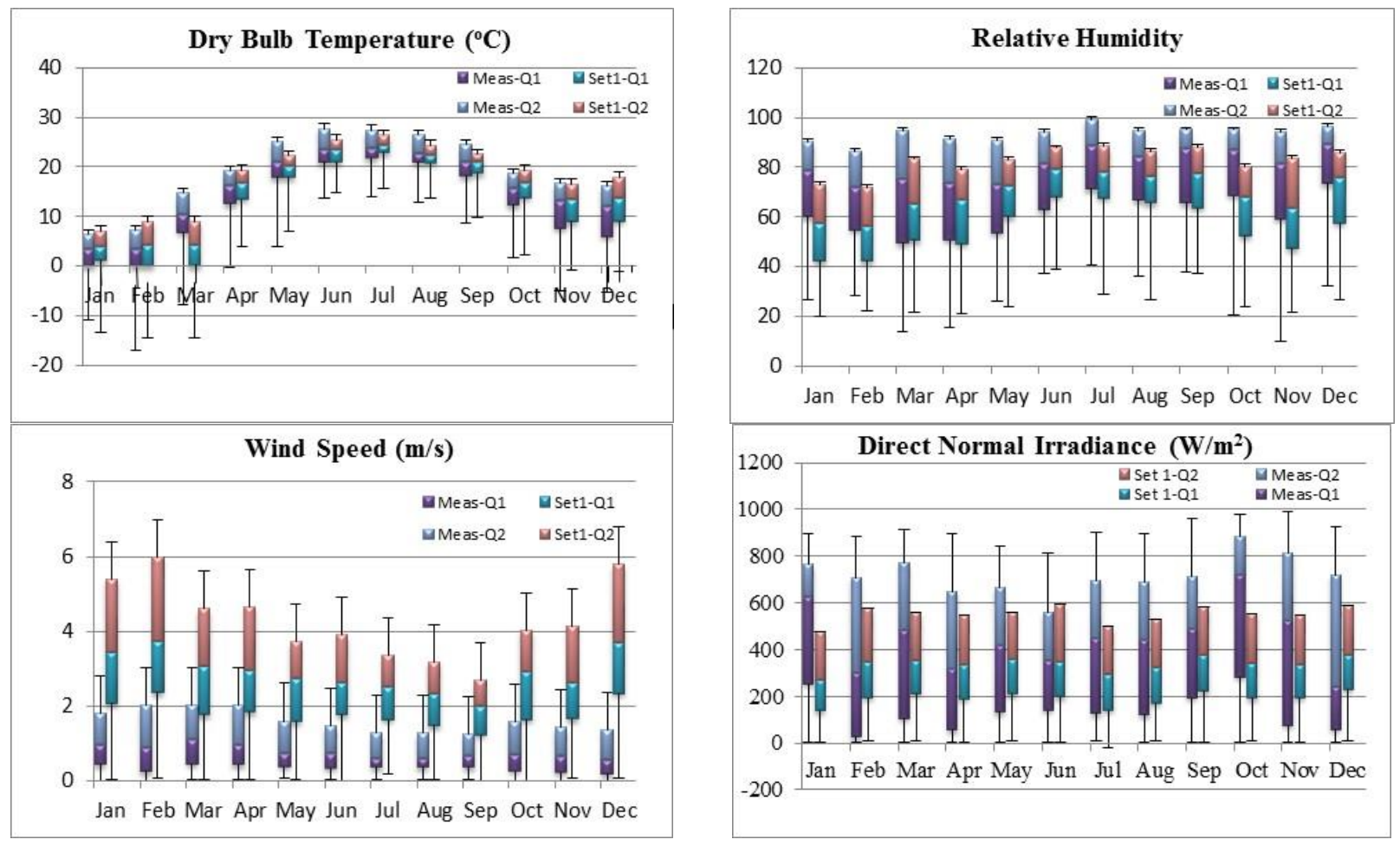


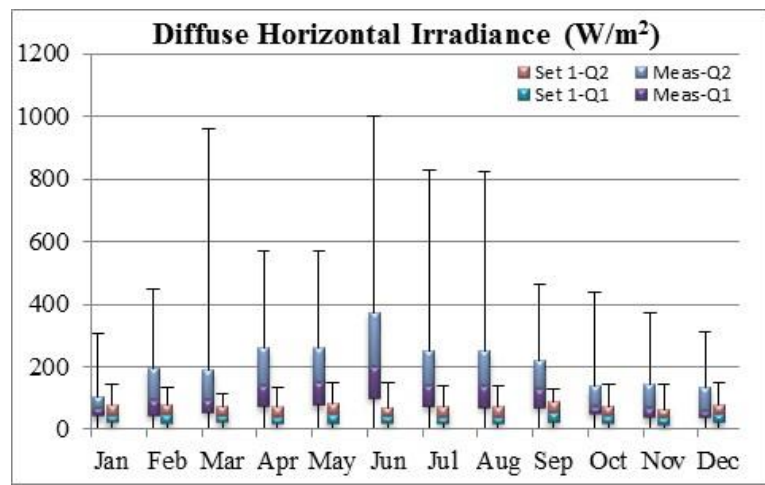

Figure 7. Box-and-whisker plots of hourly dry bulb, relative humidity, wind speed, direct normal irradiance (DNI), and diffuse horizontal irradiance (DHI) for each month shows the statistical differences between measured and simulated weather variables. Lines show the maximum and minimum value, where vertical bars meet is the average monthly data value, bars show the $25-50^{\text {th }}$ percentile and $50-75^{\text {th }}$ percentile of hourly data for that month. Charts for DNI, and DHI show data for daylight hours only.

As seen in Figure 7, there is a reasonable similarity in pattern between the simulated and measured data for dry bub temperature and RH but wind speed, direct normal and diffuse irradiance are way off. This large difference might be due to the offline calculation and not necessarily of the WRF model

Figure 8 show the frequency distribution of dry bulb temperature, wind speed, direct normal and diffuse irradiance. The negative values of diffuse radiations in simulation model data were assumed to be zero. Again, except the ambient temperature, the other variables show a large variation between simulated and measured data.
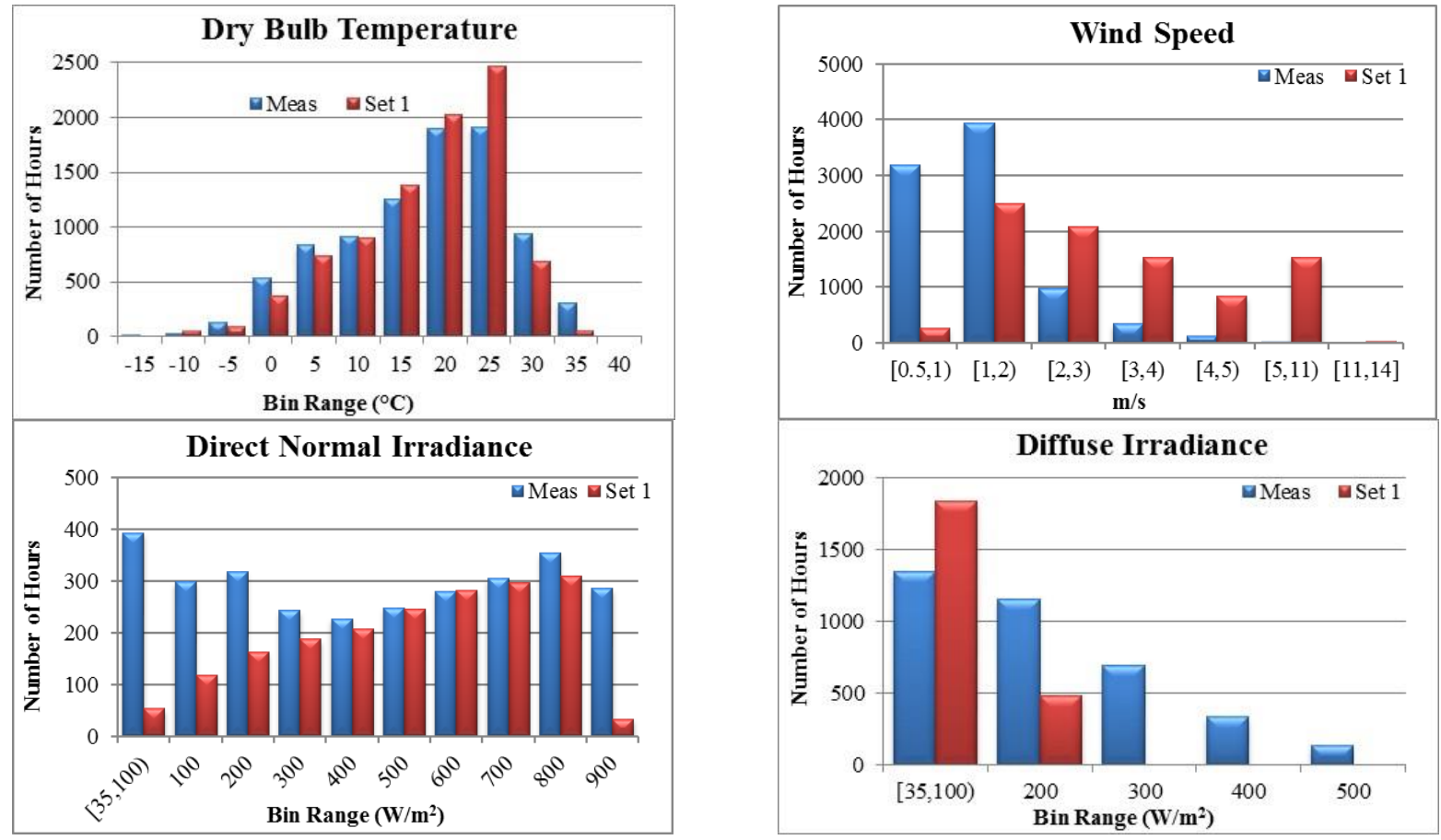

Figure 8: Frequency distribution of values within specific weather variables. 
Figure 9 shows the scatter plot of annual comparison of measured vs WRF calculated dry bulb temperature data. The figure shows that the correlation is highly biased and further improvements in calculated data can be made.

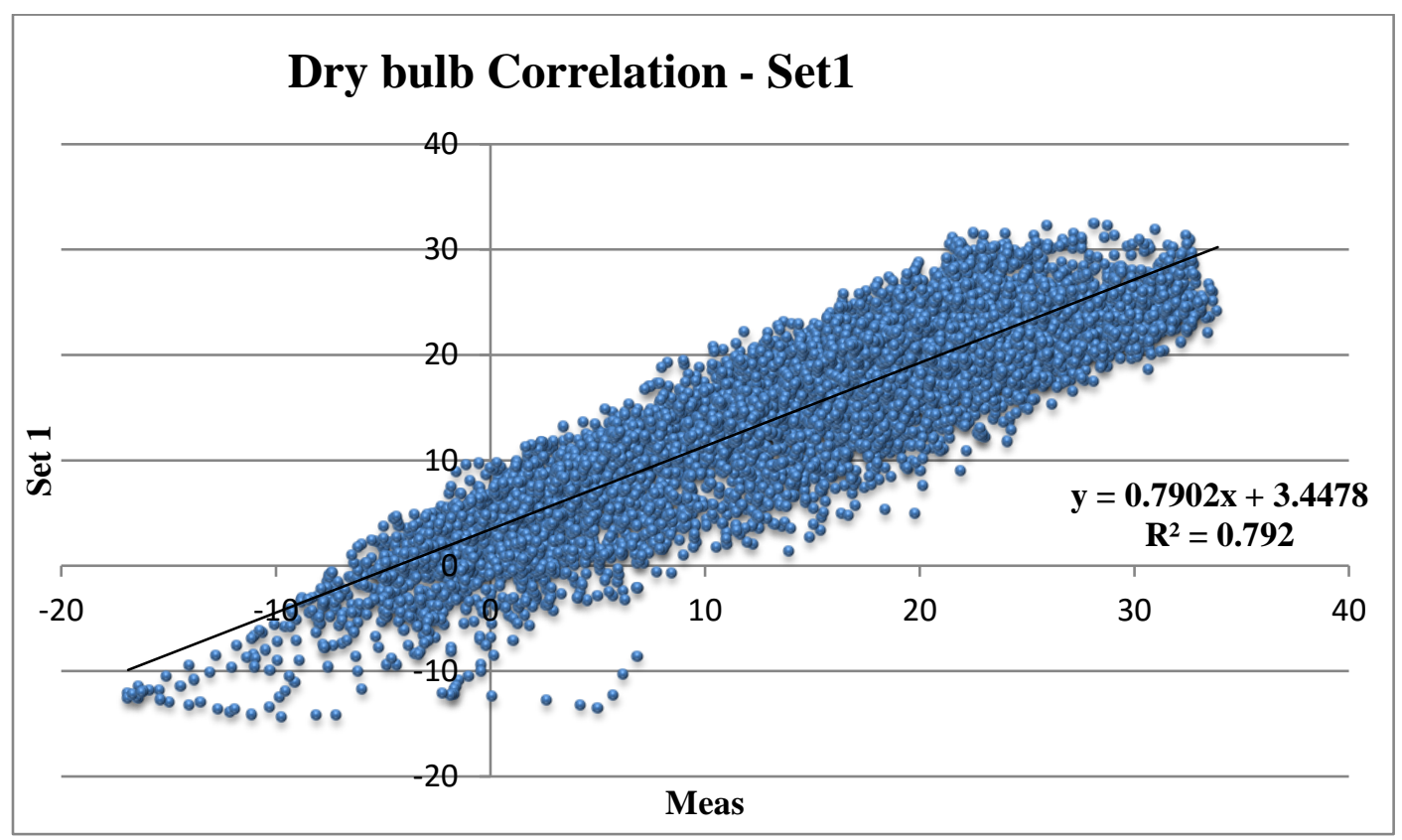

Figure 9: Frequency distribution of values within specific weather variables.

Figure 10 shows monthly heating and cooling degree days on $18^{\circ} \mathrm{C}$ base for WRF at 270 meter spatial resolution (domain 3), measured and Typical Meteorological Year (TMY) data set. TMY data was used for comparison as this is the most common data used by the energy modeler for whole building energy analysis in absence of actual weather data. It appears that the WRF simulated data over predict both heating and cooling degree days by an annual average of $10 \%$ and $4 \%$ respectively.
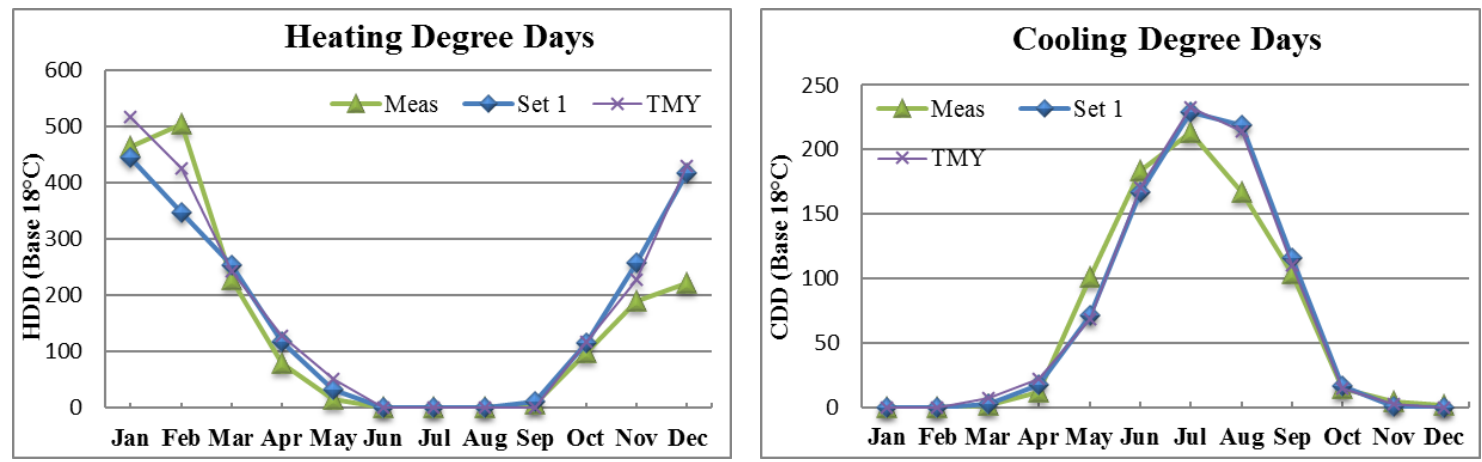

Figure 10 : Heating and cooling degree days 


\subsection{WHOLE BUILDING ENERGY ANALYSIS}

In order to ascertain the impact of weather data on the annual heating and cooling loads, three representative buildings were selected for comparative simulations: a medium office (Bldg 1-4,982 $\mathrm{m}^{2}$ ), a highly efficient residential home (Bldg $2-382 \mathrm{~m}^{2}$ ) and a Home Energy Rating System Building Energy Simulation Test (HERS BESTEST [13]) Case L100A building (Bldg 3-143 $\mathrm{m}^{2}$ ). EnergyPlus was used to estimate energy use by these buildings when measured weather data is used and when WRF weather data is used. Figure 11 shows the building models created in EnergyPlus.

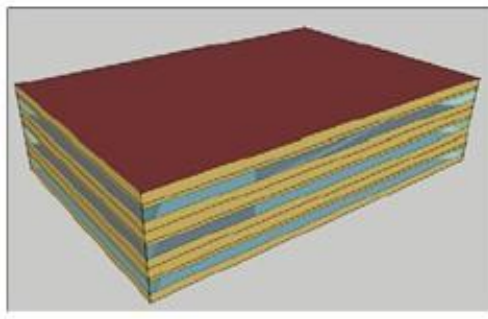

(a)

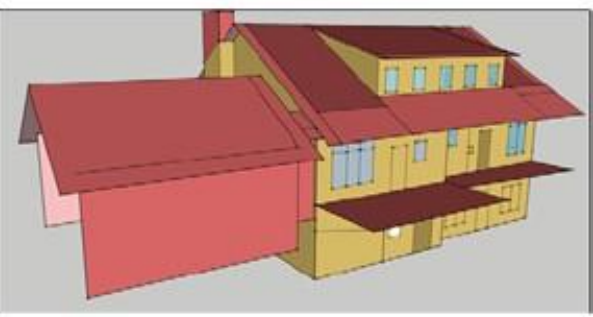

(b)

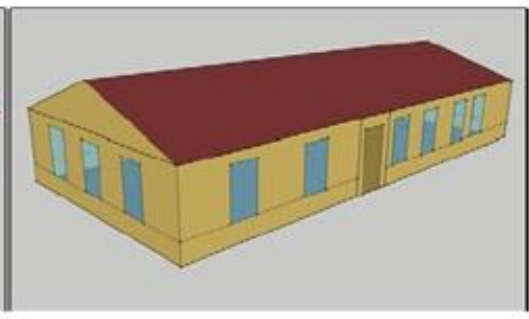

(c)

Figure 11: EnergyPlus model of buildings: (a) Building 1, (b) Building 2 and (c) Building 3

Figure 12 shows the monthly heating and cooling loads of the buildings with variation in weather data source i.e. measured and Set 1 and TMY data.
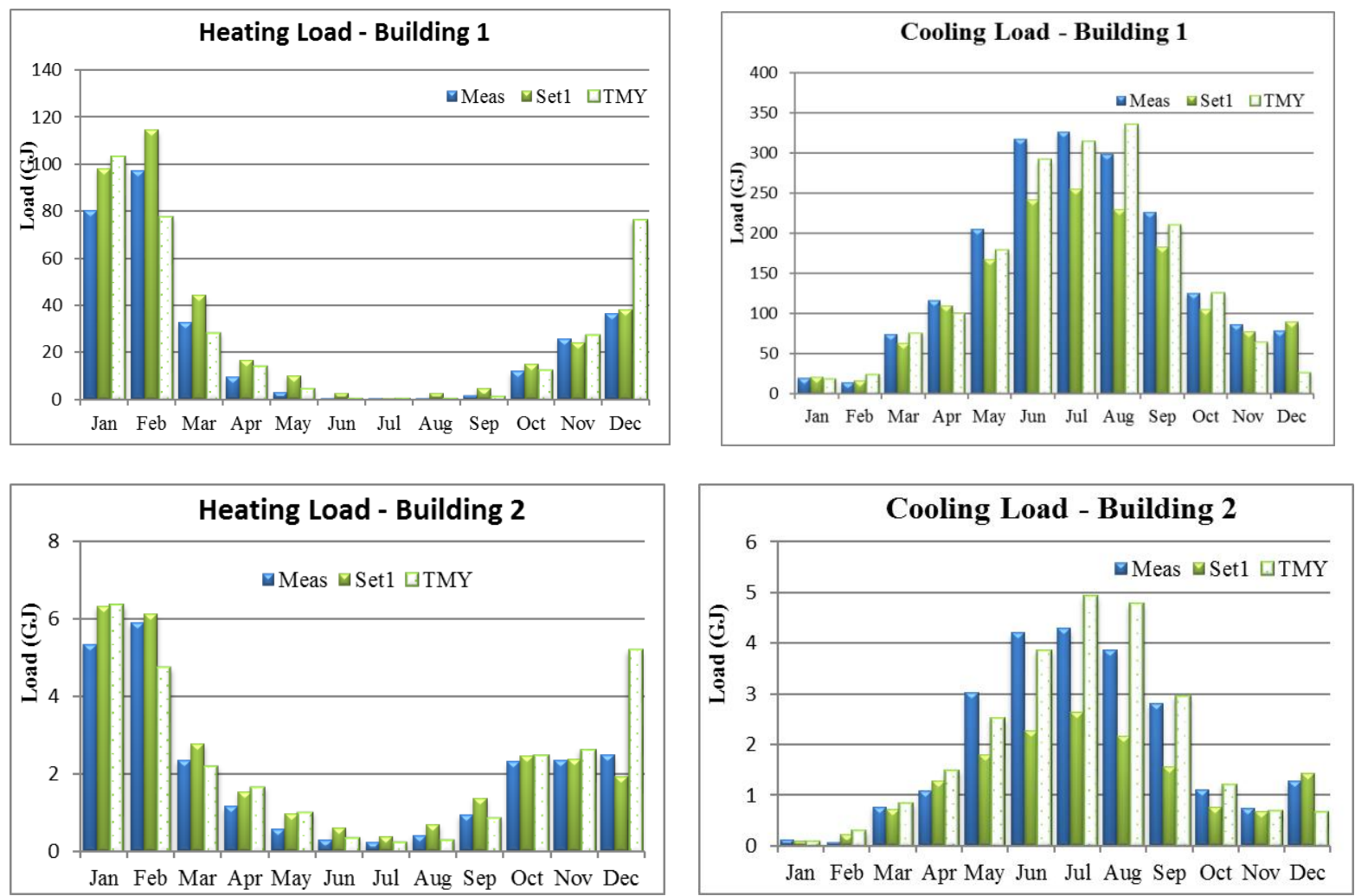

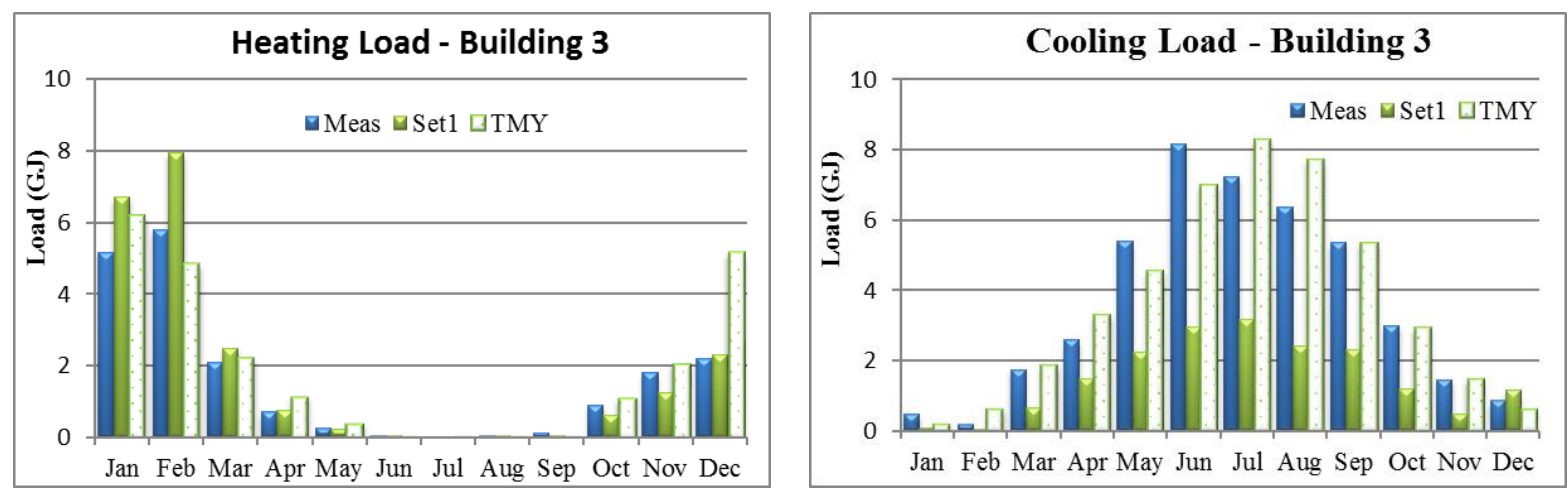

Figure 12 : Monthly Heating and cooling loads

Figure 12 shows that, the heating loads calculated using measured and WRF simulated (Set 1) weather data match within reasonable accuracy but the cooling loads calculated by Set 1 is very small as compared to the cooling loads calculated using measured weather data. Table 4 shows the annual energy consumption using both set of weather data, actual difference and percentage difference.

Table 4. Variation in annual energy consumption with respect to weather data

\begin{tabular}{|c|c|c|c|}
\hline \multicolumn{4}{|c|}{ Annual Energy Consumption (GJ) } \\
\hline & Meas & Set 1 & TMY \\
\hline Bldg $1\left(4982 \mathrm{~m}^{2}\right)$ & 2781.89 & 2928.3 & 2806.15 \\
\hline Diff & & 146.41 & 24.26 \\
\hline$\%$ Diff & & $5.26 \%$ & $0.87 \%$ \\
\hline Bldg $2\left(382 \mathrm{~m}^{2}\right)$ & 89.54 & 86.03 & 93.22 \\
\hline Diff & & -3.51 & 3.68 \\
\hline$\%$ Diff & & $-3.92 \%$ & $4.11 \%$ \\
\hline Bldg $3\left(143 \mathrm{~m}^{2}\right)$ & 36.31 & 31.47 & 41.57 \\
\hline Diff & & -4.84 & 5.26 \\
\hline$\%$ Diff & & $-13.33 \%$ & $14.49 \%$ \\
\hline
\end{tabular}

It is interesting to note that even the measured and Set 1 weather data do not match well, the simulated annual energy consumption between these two weather data set is similar. This small variation is caused as the impact due to the variation in different weather parameters cancels out the large difference in individual weather variables. To observe the difference dues to these individual weather variables, a sensitivity analysis was carried out where the variable in the measured data were replaced by individual variables from the Set 1 data. For example, the dry bulb temperature in measured weather data file was replaced by the dry bulb temperatures calculated by WRF model while keeping all other measured variables. These weather files were then used for simulating all the three buildings for finding the annual energy consumption. 

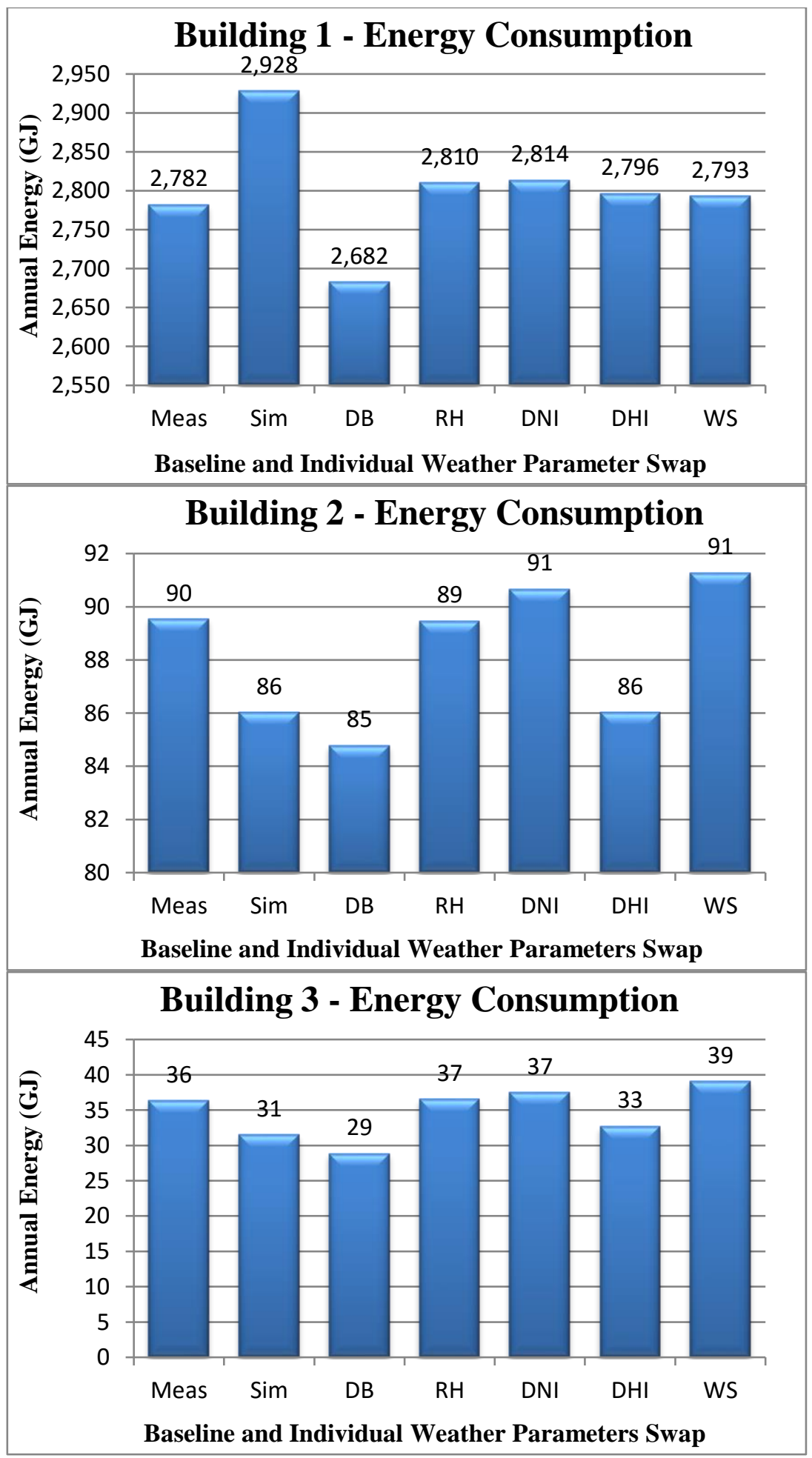

Figure 13 : Annual energy consumption using measured weather data as well where individual parameters from Set 1 are used to replace the measured weather data for variables including: dry bulb temperature (DB), relative humidity (RH), direct normal irradiance (DNI), diffuse horizontal irradiance (DHI)and wind speed (WS). 


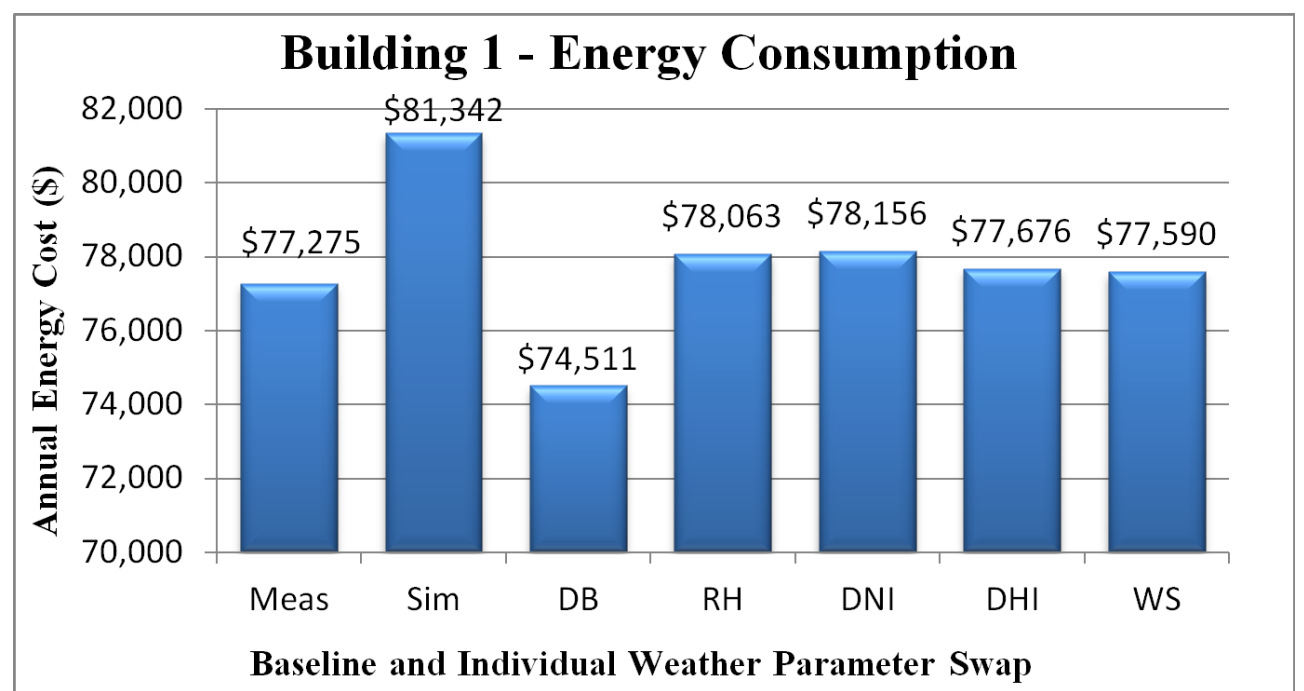

Figure 14. Annual energy consumption reported in the above figure is converted to USD for relative comparison of each variable's contribution to the anticipated energy cost for owning the building.

Figure 13 shows annual energy consumption for each of the 3 buildings using: measured weather data, microclimate simulation weather data, followed by individual simulated variables replacing the same variable from the measured data to show the impact of each simulated variable on building energy use. In an effort to make Figure 13 more easily interpretable, Figure 14 shows the energy use in terms of total annual energy costs. There is no clear trend in terms of impact of an individual variable across all the building type, as far as the impact of an individual weather variable is concerned. The dry bulb temperature, even though it is a closest match between the measured and Set 1 data, shows the largest variance in annual energy consumption.

\section{CONCLUSIONS}

Annual weather data for Oak Ridge, TN campus were generated using ENVI-met and WRF models on ORNL's Titan supercomputer and compared to ASHRAE Clear Sky Model and measured weather data. This report charts and statistically summarizes the distribution of errors for each of the meteorological weather variables used and translates that into energy consumption of three prototype buildings. While weather variables differ substantially, and monthly heating and cooling loads are quite different, the total annual energy consumption of the buildings using measured versus simulated weather data is similar. A simple sensitivity analysis shows that there is no clear trend of the impact of various weather variables across all three different building types. This work highlights discrepancies between the current WRF simulations and measured data that we anticipate will help prioritize and correct these simulations in future work. 


\section{REFERENCES}

[1] DOE (2010). Building Energy Data Book. Available: http://buildingsdatabook.eren.doe.gov.

[2] Pincetl, S., P. Bunje, and T. Holmes (2012). An expanded urban metabolism method: towards a systems approach for assessing the urban energy processes and causes, Landscape and Urban Planning, 107, 193-202.

[3] Dorer, V., J. Allegrini, K.Orehounig, P. Moonen, G. Upadhyay, J. Kampf, and J. Carmeliet (2013). Modeling the urban microclimate and its impact on the energy demand of buildings and building clusters. Proceedings of BS2013: 13th Conference of International Building Performance Simulation Association, 3483-3489. Chambery, France. International Building Performance Simulation Association.

[4] Hadley, S. W., D.J. Erickson III, and J.L. Hernandez (2006). Responses of energy use to climate change: A climate modeling study, Geophysical Research Letters, 33, L17703, doi:10.1029/2006GL026652.

[5] Chung, M. and H.-C. Park (2010). Development of a software package for community energy system assessment--Part I: Building a load estimator, Energy, 35, 2767-2776.

[6] Gouveia, J.P., P. Fortes, and J. Seixas (2012). Projections of energy services demand for residential buildings: Insights from a bottom-up methodology, Energy, 47, 430-442.

[7] Dirks, J.A., W.J. Gorrissen, J.H. Hathaway, D.C. Skorski, M.J. Scott, T.C. Pulsipher, M. Huang, Y. Liu, J.S. Rice (2015). Impacts of climate change on energy consumption and peak demand in buildings: A detailed regional approach, Energy, 79, 20-32.

[8] Kodysh, J.B., O.A. Omitaomu, B.L. Bhaduri and B.S. Neish (2013). Methodology for estimating solar potential on multiple building rooftops for photovoltaic systems, Sustainable Cities and Society, 8, 31-41.

[9] Oleson, K.W., G.B. Bonan, J. Feddema, M. Vertenstein, and E. Kluzek (2010). Technical Description of an Urban Parameterization for the Community Land Model (CLMU). NCAR Technical Note NCAR/TN-480+STR, DOI: 10.5065/D6K35RM9.

[10] ASHRAE . 2013. ASHRAE Handbook Fundamentals. ASHRAE. 1791 Tullie Circle, N.E., Atlanta, GA.

[11] DOE, 2013. EnergyPlus Input/Output Reference and Engineering Reference for EnergyPlus version 8.1. Available: http://apps1.eere.energy.gov/buildings/energyplus/energyplus_documentation.cfm

[12] Buckberry, Heather L. and M. Bhandari, "ORNL MAXLAB Flexible Research Platforms.” 2012 ACEEE Summer Study on Energy Efficiency in Buildings Proceedings.

[13] NREL/TP-472-7332a, Home Energy Rating System Building Energy Simulation Test (HERS BESTEST). Volume 1, 1995.

[14] Department of Energy, EnergyPlus Energy Simulation Software - Weather Data Sources, 2011. Available WWW: http://apps1.eere.energy.gov/buildings/energyplus/weatherdata_sources.cfm. 